\title{
Improved biosurfactant production from Aspergillus niger through chemical mutagenesis: characterization and RSM optimization
}

\author{
Muhammad Asgher $^{1} \cdot$ Sadaf Arshad ${ }^{1} \cdot$ Sarmad Ahmad Qamar $^{1}$ (D) Nimrah Khalid
}

Received: 25 February 2020 / Accepted: 15 April 2020 / Published online: 25 April 2020

(c) Springer Nature Switzerland AG 2020

\begin{abstract}
Biosurfactants are surface-active natural polymers produced within several microorganisms and are secreted outside the cellular environment. They are the focus of modern researches due to their eco-friendly nature and high production capability using low-cost agro-industrial wastes. In this research, we have evaluated Aspergillus niger (A. niger) for its biosurfactant production potential during solid state fermentation of banana stalks powder. The native strain of $A$. niger produced $2.3 \mathrm{~g} / \mathrm{L}$ of biosurfactant with $49.74 \mathrm{~cm}^{2}$ oil displacement, $57 \%$ emulsification index and an emulsification activity of $1.024\left(\mathrm{OD}_{540}\right)$. Sequential mutagenesis was induced in the native strain of $A$. niger by exposing the strain with different concentrations of ethidium bromide $(\mathrm{EtBr})$, for different time periods. Significantly higher amount of biosurfactant ( $3.3 \mathrm{~g} / \mathrm{L}$ ) was obtained from the mutant strain A. niger M2 exposed to $50 \mu \mathrm{g} / 10 \mathrm{~mL}$ of EtBr for $60 \mathrm{~min}$. The screening tests revealed the improvement in oil displacement $\left(59.81 \mathrm{~cm}^{2}\right)$, emulsification index $(62.3 \%)$ and emulsification activity $\left(\mathrm{OD}_{540}, 1.262\right)$ of biosurfactant. FTIR analysis confirmed the presence of amine, amide, fatty acids and triglycerides functional groups. The maximum biosurfactant synthesizing mutant (A. niger M2) was further optimized using RSM under CCD. After optimization, the highest biosurfactant $(5.50 \mathrm{~g} / \mathrm{L})$ was obtained at $35^{\circ} \mathrm{C}$ temperature, 7 $\mathrm{pH}, 5.75 \mathrm{~g}$ substrate concentration and $168 \mathrm{~h}$ of overall incubation period. In conclusion, the cost-effective production of biosurfactant, along with novel structural and multifunctional characteristics, this study may be useful for different industrial and biotechnological applications.
\end{abstract}

Keywords Biosurfactant $\cdot$ Aspergillus niger $\cdot$ Mutagenesis $\cdot$ Structural properties $\cdot$ Statistical optimization . Characterization

\section{Introduction}

Surfactants are surface-active chemical substances which have gained high importance in fluid mechanics because of their ability to reduce surface tension of liquids. Most of these surface-active compounds are synthesized chemically, which are causing serious toxicological and environmental problems. Biosurfactants are biopolymers, produced by several microorganisms (bacteria and fungi), which possess hydrophobic and hydrophilic moieties. They provide the best alternative to synthetic surfactants in term of low toxicity, high biodegradability, environmentally friendly nature, and the production capability using low-cost agro-industrial raw materials "green technology" [1]. Biosurfactants comprise a large group of chemical compounds e.g. glycolipids, lipopeptides, phospholipids, lipoproteins and lipid-polysaccharide complexes [2]. They present various applications as emulsifiers, conditioners, cosmetics and food industries [3, 4].

Biosurfactants have been reported to possess excellent biomedical and therapeutic properties [5-8] and also found to be effective to tackle environmental pollution

Sarmad Ahmad Qamar, sarmad_qamar@uaf.edu.pk| ${ }^{1}$ Department of Biochemistry, University of Agriculture, Faisalabad, Pakistan. 
through bioremediation [4, 9]. They are important in food digestion and respiratory action, plant pathogenicity, paints, beverages, cosmetics and cement industries. Moreover, biosurfactants can be produced from renewable resources and commonly effective in extreme environmental conditions. Biosurfactants also have applications in laundry formulations, pesticides and herbicides, agriculture, textile, household cleaning products, detergents, petroleum and paper industries, food processing, and pharmaceutical industries. They are also important in enzyme biotechnology because of their regulatory effects and bio-stimulatory effects [10].

Surfactant display properties like foaming, emulsification, detergency and dispersion [11-13]. Microorganisms have ability to produce different kinds of surfactants, from these, high molecular weight polymers are highly efficient emulsifiers [14, 15], while low molecular weight polymers efficiently reduce interfacial and surface tension of liquids [16]. Biosurfactants can bear extreme environmental conditions e.g., wide range of $\mathrm{pH}$, high salinity and temperature [17]. In previous decade, much attention has been devoted towards biosurfactants because of their exceptional functional properties. These properties allow a possible replacement of chemically synthesized surfactants for a number of industrial and biotechnological operations [18].

The identification and optimization of fermentation parameters that influence the surfactant yield represent the major points for the development of cost-effective procedures [19]. There are several different factors controlling the microbial biosurfactant production during fermentation which are needed to be maintained within a specific range. It will allow maximum microbial multiplication, which ultimately leads to higher biosurfactant production. In this regard, several physical and nutritional parameters are needed to be optimized for enhance biosurfactant yield. The yield of biosurfactant highly depends upon the availability of carbon and nitrogen sources and other limiting nutrients [20]. Factors influencing biosurfactant production have extensively been investigated particularly for Pseudomonas spp. [21, 22], Candida spp. [23-25], Rhodococcus spp. [26, 27] There is a dirt of information related to biosurfactant production from bacterial spp. and the optimization of several nutritional and physical parameters influencing the overall yield [28-30].

Microbial biosurfactant production can only be maximized if fermentation parameters are maintained at the optimal growth conditions of microbe. For this purpose, one of the most appropriate approach could be response surface optimization. RSM is a combination of statistical and mathematical tool that is frequently being used in fermentation biotechnology for optimization of fermentation parameters [31-33]. RSM is a statistical design experimental process in which several factors are varied simultaneously. In fact, the relationship between the independent variables and the response variable is usually unknown in an experiment. Therefore, the initial step is to approximate the response variable through analyzing the independent variables.

This study was designed to investigate $A$. niger for its ability to synthesize biosurfactant. The native fungal strain was mutated using different concentrations of $\mathrm{EtBr}$ for different time periods. The lyophilized biosurfactant from both native and mutant strain was structurally characterized using FT-IR spectroscopy. The maximum biosurfactant producer mutant strain (A. niger M2) was further optimized using RSM under CCD. An insight of primary characteristics of fungal biosurfactant have also been provided in this article.

\section{Materials and methods}

\subsection{Materials}

Banana stalks were obtained from Botanical Garden of University of Agriculture, Faisalabad (UAF), Pakistan. After pretreatment, stalks were chopped and placed in the incubator (LabTech LDO-150 N) at $50^{\circ} \mathrm{C}$ for $48 \mathrm{~h}$. The dried substrate was ground into fine powder and stored in an airtight jar at $25^{\circ} \mathrm{C}$ temperature. All other chemicals/materials used in this study were obtained from distributors of international companies (Merck KGaA, USA and Sigma Aldrich, Germany).

\subsection{Fungal strain}

Purified culture of a black rot fungus (A. niger) was collected from Industrial Biotechnology Laboratory of UAF, Pakistan. Culture was streaked on a freshly prepared PDA slants of $\mathrm{pH} 6.5$ and incubated at $35^{\circ} \mathrm{C}$ temperature for 6-8 days. Fungal spore suspension was prepared by transferring the culture to Vogel's minimal media [34]. Media was added with glucose $(2 \%)$ as carbon source and placed in shaking incubator at $160 \mathrm{rev} / \mathrm{min}$ and $37^{\circ} \mathrm{C}$ temperature.

\subsection{Chemical mutagenesis}

Ethidium bromide (EtBr) was used for the induction of mutation in A. niger. For this purpose, mutagen stock solution was prepared by the addition of $\mathrm{EtBr} 500 \mu \mathrm{g} / 10 \mathrm{~mL}$ of distilled water. Solutions of different concentrations i.e. $50,100,150$ and $200 \mu \mathrm{g} / 10 \mathrm{~mL}$ were prepared from $\mathrm{EtBr}$ stock. Serial dilutions of vegetative cells of fungal inoculum were formed and pellets were suspended in $\mathrm{EtBr}$ solution for different time periods of 30,60 and $90 \mathrm{~min}$. The 
fungal suspension was centrifuged, and the pellets were washed thrice with saline solution [composition $(\mathrm{g} / \mathrm{L})$ of $\mathrm{NaCl}$ (8.9) and yeast extract (1.0) in $\mathrm{dd}_{2} \mathrm{O}$ ]. Agar media containing triton $\mathrm{X}-100$ was used for the development of genetically modified colonies [35]. The final screening of mutant colonies was achieved by using 2-deoxy-D-glucose as metabolic inhibitor that was used for the isolation of mutant strains [36]. The inocula were prepared from native as well as selected mutant strain and preserved at refrigerator temperature $\left(4^{\circ} \mathrm{C}\right)$.

\subsection{Development and recovery of biosurfactant}

The solid-state fermentation was carried out using banana stalk powder $(5 \mathrm{~g})$ as substrate moistened with $5 \mathrm{~mL}$ of fungal growth suspension prepared by mixing $\mathrm{g} / \mathrm{L}$ of $\mathrm{NaNO}_{3}(3.0), \mathrm{MgSO}_{4} .7 \mathrm{H}_{2} \mathrm{O}(0.5), \mathrm{KH}_{2} \mathrm{PO}_{4}(1.0)$, yeast extract (1.0) and peptone (3.0) with a pH 7.0. The media was sterilized by autoclaving for $20 \mathrm{~min}$ at $121{ }^{\circ} \mathrm{C}$ temperature. Fermentation medium was added with $2 \mathrm{~mL}$ of $A$. niger inoculum containing $10^{7}$ spores $/ \mathrm{mL}$ and incubated at $37^{\circ} \mathrm{C}$ for 6-8 days. All the experiments were conducted in triplicate. Media was centrifuged for $20 \mathrm{~min}$ at $5600 \mathrm{rev} / \mathrm{min}$ to get cell-free supernatant. Cell-free supernatant was acidified with $6 \mathrm{~N} \mathrm{HCl}$ to get a final $\mathrm{pH}$ of 2.0 and was kept in refrigerator temperature $\left(4^{\circ} \mathrm{C}\right)$ for the precipitation of lipids and proteins [1]. The pallets were harvested by centrifugation for $15 \mathrm{~min}$ at 10,000 rev/min and $\mathrm{pH}$ was adjusted to normal by the addition of sufficient amount of distilled water. The extracted pallets were lyophilized for the quantification of biosurfactant.

\subsection{Screening of biosurfactant}

\subsubsection{Oil displacement}

Oil displacement was performed using the method adopted from Morikawa et al. [37] with little modifications. Briefly, distilled water $(40 \mathrm{~mL})$ was poured in a glass petri plate of $90 \mathrm{~mm}$ diameter. Cottonseed oil $(8.0 \mathrm{~mL})$ was poured on the water surface to form a thin layer. Cellfree supernatant containing biosurfactant $(3 \mathrm{~mL})$ was gently poured at the center of petri plate. The area $\left(\mathrm{cm}^{2}\right)$ of displaced oil layer was measured for determination of biosurfactant.

\subsubsection{Emulsification index}

Emulsification index $\left(\mathrm{E}_{24}\right)$ was determined by the method of Alvarez et al. [38]. Briefly, the cell free supernatant was added in the cottonseed oil with 3:2 (biosurfactant: oil) ratio. The mixture was gently vortexed, and the height $(\mathrm{cm})$ of emulsion layer and total height of solution was calculated after $24 \mathrm{~h}$. The emulsification index was calculated by using the equation.

Emulsification index $\left(\mathrm{E}_{24}\right)=\frac{\text { Hight of emulsion layer }(\mathrm{cm})}{\text { Total hight of solution }(\mathrm{cm})} \times 100$

\subsubsection{Emulsification activity assay}

The determination of emulsification assay was performed by the method described by Patel and Desai, [39]. Briefly, a solution of Tris-Mg was prepared by the addition of Tris- $\mathrm{HCl}(20 \mathrm{mM})$ and $\mathrm{MgSO}_{4}(10 \mathrm{mM})$ with a final $\mathrm{pH}$ of 8.0. Tris-Mg solution $(7.5 \mathrm{~mL})$ was added in a test tube and added with $0.5 \mathrm{~mL}$ of cell-free supernatant (biosurfactant) and $0.1 \mathrm{~mL}$ of kerosene oil. The tubes were gently vortexed and allowed to stand for $60 \mathrm{~min}$. Absorbance was recorded at $540 \mathrm{~nm}$ using UV/visible spectrophotometer (Dynamica Scientific, HALO DB-20). Patel and Desai (1997) described the emulsification activity as the measured optical density of a sample. The activity was calculated by using the following relationship:

Emulsification activity $\left(\mathrm{OD}_{540}\right)=A / L$

here ' $\mathrm{A}$ ' is absorbance and ' $\mathrm{L}$ ' is optical pass length.

\subsection{Structural characterization of biosurfactant}

\subsubsection{Fourier transform infrared spectroscopy (FT-IR)}

Biosurfactant obtained from native as well as mutant strains of $A$. niger was analyzed using FT-IR (Bruker Alpha FTIR, Germany) for the detection of major functional groups. The lyophilized biosurfactant samples $(0.5 \mathrm{mg})$ were placed directly under the infrared beam and spectrum was recorded at $500-4000 \mathrm{~nm}$ wavelength for detailed structural analysis.

\subsection{Optimization of biosurfactant production}

Optimization is a technique used to get the best possible results with maximum achievable performance and costeffectiveness under certain limitations. The biosurfactant production from mutant $A$. niger was optimized using response surface methodology (RSM) under central composite design (CCD). RSM is a combination of statistical and mathematical techniques used to analyze the effect of dependent variables on one or more independent variables (response). Four parameters i.e., temperature (X1), $\mathrm{pH}(\mathrm{X} 2)$, incubation time (X3) and substrate concentration (X4) were optimized using four-factors, six-level CCD requiring 30 runs with six central points and a 0.5 . The biosurfactant was harvested by acid-precipitation followed by 
centrifugation at $10,000 \mathrm{rev} / \mathrm{min}$ for $15 \mathrm{~min}$. The extracted biosurfactant was freeze-dried and weighted for quantification. The RSM model was designed using Design Expert software v11.1.0.1.

\section{Results}

\subsection{Screening for best biosurfactant producer strain}

Biosurfactant produced by native strain of $A$. niger ( $2.3 \mathrm{~g} / \mathrm{L})$ showed $49.74 \mathrm{~cm}^{2}$ oil displacement area, $57 \%$ emulsification index and 1.024 emulsification activity. The wild fungal strain was mutated with $\mathrm{EtBr}$ to determine the consequence of mutagenesis on total biosurfactant yield. Table 1 summarizes the data obtained after sequential mutagenesis in $A$. niger using different concentrations and exposure time to mutagen (EtBr). Maximum biosurfactant yield $(3.3 \mathrm{~g} / \mathrm{L})$ was attained from A. niger M2 specie exposed to $50 \mu \mathrm{g} / 10 \mathrm{~mL} \mathrm{EtBr}$ for $60 \mathrm{~min}$. In addition, screening tests revealed an emulsification index of $62.30 \%$ and emulsification activity of $1.262\left(\mathrm{OD}_{540}\right)$ with oil displacement area of $59.81 \mathrm{~cm}^{2}$. All the mutants produced significant amount of biosurfactant ranging from $1.5-3.3 \mathrm{~g} / \mathrm{L}$ depending upon mutagen concentration and exposure time (Fig. 1a). Figure $1 \mathrm{~b}$ provides a representation of emulsification index $\left(E_{24}\right)$ from different mutant strains of $A$. niger. The emulsification and oil displacements conformed the biosurfactant production, and the dry weight estimation after lyophilization made the selection easier for maximum producing mutant colonies (A. niger M2) which was subjected to RSM optimization.
Table 1 Screening of $A$. niger mutants for their biosurfactant production potential depending upon total biomass, oil displacement area, emulsification index and emulsification activity

\begin{tabular}{lllllll}
\hline $\begin{array}{l}\text { EtBr conc. } \\
(\mu \mathrm{g} / 10 \mathrm{~mL})\end{array}$ & Mutant strain ID & $\begin{array}{l}\text { Exposure } \\
\text { time } \\
(\mathrm{min})\end{array}$ & $\begin{array}{l}\text { Displace- } \\
\text { ment area } \\
\left(\mathrm{cm}^{2}\right)\end{array}$ & $\begin{array}{l}\text { Emulsifica- } \\
\text { tion index } \% \\
\left(\mathrm{E}_{24}\right)\end{array}$ & $\begin{array}{l}\text { Emulsification } \\
\text { activity }\left(\mathrm{OD}_{540}\right)\end{array}$ & $\begin{array}{l}\text { Biosur- } \\
\text { factant yield } \\
(\mathrm{g} / \mathrm{L})\end{array}$ \\
\hline 50 & M1 & 30 & $47.76 \pm 3.44$ & $57.63 \pm 2.30$ & $1.024 \pm 0.01$ & $2.9 \pm 0.20$ \\
& M2 & 60 & $59.81 \pm 4.20$ & $62.30 \pm 2.41$ & $1.262 \pm 0.00$ & $3.3 \pm 0.21$ \\
& M3 & 90 & $52.78 \pm 4.01$ & $59.95 \pm 1.80$ & $1.175 \pm 0.01$ & $3.0 \pm 0.18$ \\
100 & M4 & 30 & $30.18 \pm 3.32$ & $42.45 \pm 2.81$ & $0.820 \pm 0.03$ & $2.1 \pm 0.28$ \\
& M5 & 60 & $37.37 \pm 3.41$ & $47.50 \pm 2.73$ & $0.963 \pm 0.02$ & $2.6 \pm 0.30$ \\
& M6 & 90 & $35.24 \pm 3.00$ & $47.23 \pm 2.89$ & $0.894 \pm 0.01$ & $2.7 \pm 0.27$ \\
& M7 & 30 & $25.50 \pm 2.91$ & $39.60 \pm 2.31$ & $0.679 \pm 0.00$ & $1.6 \pm 0.10$ \\
& M8 & 60 & $24.62 \pm 3.31$ & $38.24 \pm 2.40$ & $0.652 \pm 0.01$ & $1.5 \pm 0.13$ \\
& M9 & 90 & $32.96 \pm 4.29$ & $43.04 \pm 2.44$ & $0.740 \pm 0.00$ & $1.7 \pm 0.11$ \\
& M10 & 30 & $40.69 \pm 4.10$ & $49.90 \pm 7.20$ & $0.826 \pm 0.00$ & $1.9 \pm 0.51$ \\
& M11 & 60 & $44.39 \pm 6.21$ & $63.45 \pm 7.61$ & $1.260 \pm 0.02$ & $3.0 \pm 0.39$ \\
& M12 & 90 & $42.99 \pm 4.02$ & $61.20 \pm 6.91$ & $1.187 \pm 0.00$ & $2.4 \pm 0.42$ \\
\hline
\end{tabular}

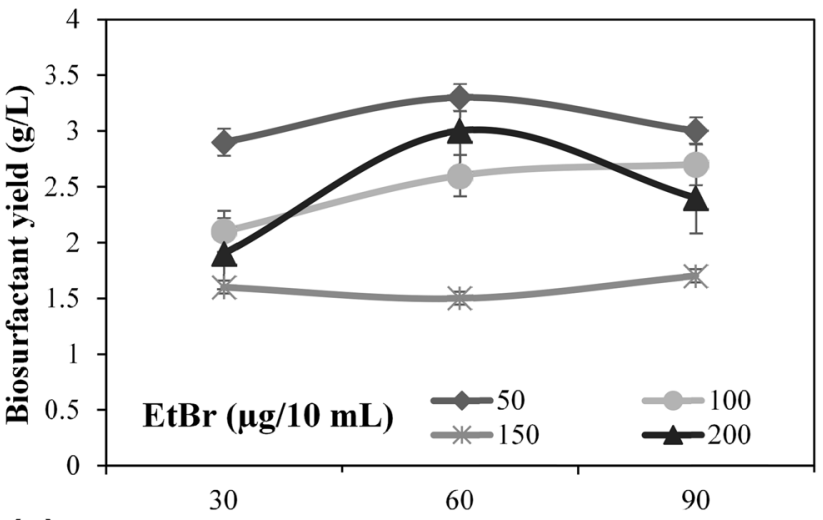

(a) Mutagen exposure time (min)

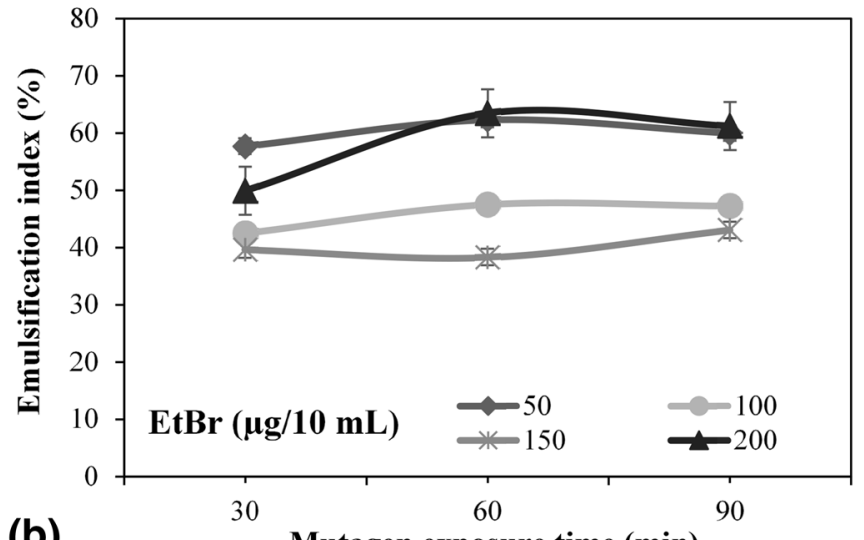

(b)

Mutagen exposure time (min)

Fig. 1 Representation of a Biosurfactant yield $\mathbf{b}$ Emulsification index $\left(\mathrm{E}_{24}\right)$ of biosurfactant produced from A. niger after exposure to different concentrations of EtBr for different time periods 


\subsection{Fermentation for biosurfactant production}

Biosurfactant production was monitored after $168 \mathrm{~h}$ of fermentation. The maximum biosurfactant production ( $3.3 \mathrm{~g} / \mathrm{L}$ ) was attained from A. niger M2 spp. with highest emulsification index of $62.30 \%$. The extraction of biosurfactant was performed using acid-precipitation. Biosurfactant is generally soluble at basic or neutral $\mathrm{pH}$ (i.e. 7). By decreasing the $\mathrm{pH}$, biosurfactant start to precipitate and increase the turbidity of the solution. This effect was determined by gradually decreasing the $\mathrm{pH}$ using $6 \mathrm{~N}$ $\mathrm{HCl}$ and taking the absorbance at $600 \mathrm{~nm}$ at UV/vis spectrophotometer (Dynamica Scientific, HALO DB-20). The maximum biosurfactant precipitation was achieved at $\mathrm{pH}$ 2. Further decrease in $\mathrm{pH}$ did not resulted any significant change (Fig. 2).

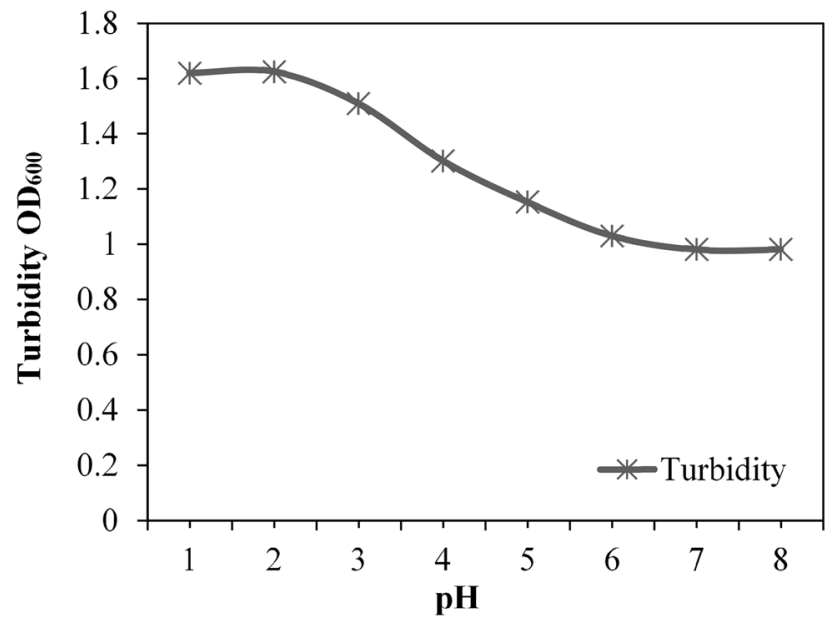

Fig. 2 Representation of biosurfactant precipitation (increase in turbidity of solution) at acidic range of $\mathrm{pH}$

\subsection{Major functional groups: FTIR}

Spectrum of biosurfactant produced from native A. niger (Fig. 3, orange line) showed a broad peak at $3366 \mathrm{~cm}^{-1}$ which shows asymmetric stretching of $\mathrm{N}-\mathrm{H}$ bonds of secondry amides of proteins. A peak at $2890 \mathrm{~cm}^{-1}$ shows strong stretching of $\mathrm{C}-\mathrm{H}$ bonds of alkane alkene and alkynes. $\mathrm{A}$ intense peak at $1655 \mathrm{~cm}^{-1}$ indicate $\mathrm{C}=\mathrm{O}, \mathrm{C}-\mathrm{N}$ stretching and $\mathrm{N}-\mathrm{H}$ bending of protein amides. A short peak at $1710 \mathrm{~cm}^{-1}$ shows the presnece of $\mathrm{C}=\mathrm{O}$ stretching of carboxylic acid, aldehyde and keton functional groups. A peak at $1500 \mathrm{~cm}^{-1}$ indicate the presence of $\mathrm{C}=\mathrm{C}$ bond of aromatic skeloton and peak at $1571 \mathrm{~cm}^{-1}$ shows $\mathrm{N}-\mathrm{H}$ bonds of amines group. Peek at $1220 \mathrm{~cm}^{-1}$ indicate the presence of $\mathrm{P}=\mathrm{O}$ bond of phosphodiester group of nuclic acid and phospholipids.

Biosurfactant from mutant strain A. niger $\mathrm{M} 2$ has been presented in Fig. 3 (blue line), which shows a broad peak at $3349 \mathrm{~cm}^{-1}$ which shows weak N-H stretching of primary and secondary amines and amides. Successive vibrations between 2000 and $2500 \mathrm{~cm}^{-1}$ indicates the presence of $\mathrm{N}-\mathrm{H}$, $\mathrm{C}-\mathrm{H}$ bonds of alkane alkene and alkynes. A peak at $1710 \mathrm{~cm}^{-1}$ show plane stretching of $\mathrm{C}=\mathrm{O}$ bond which indicate the presence of ester, lipid and triglycerides functional group. A peak at $1551 \mathrm{~cm}^{-1}$ indicates the presence of $\mathrm{N}-\mathrm{H}$ bending which is coupled with $\mathrm{C}-\mathrm{N}$ bond stretching of amide functional group. Peaks at 1456,1435 and $1400 \mathrm{~cm}^{-1}$ indicate the presence of $\mathrm{CH}_{3}$ asymmetric vibration, $\mathrm{C}-\mathrm{H}$ bending and $\mathrm{CH}_{3}$ symmetric vibrations of protein respectively. A broad peak at $1051 \mathrm{~cm}^{-1}$ shows $\mathrm{C}-\mathrm{O}$ stretch of $\mathrm{COH}$ tyrosine protein. Peek at $702 \mathrm{~cm}^{-1}$ show $\mathrm{N}-\mathrm{H}$ out of plane deformation of protein.

\subsection{Optimization of biosurfactant}

The biosurfactant yield from A. niger M2 was further optimized in SSF using statistical tools (RSM). 4-level, 6-factors CCD was used which required 30 experiments and

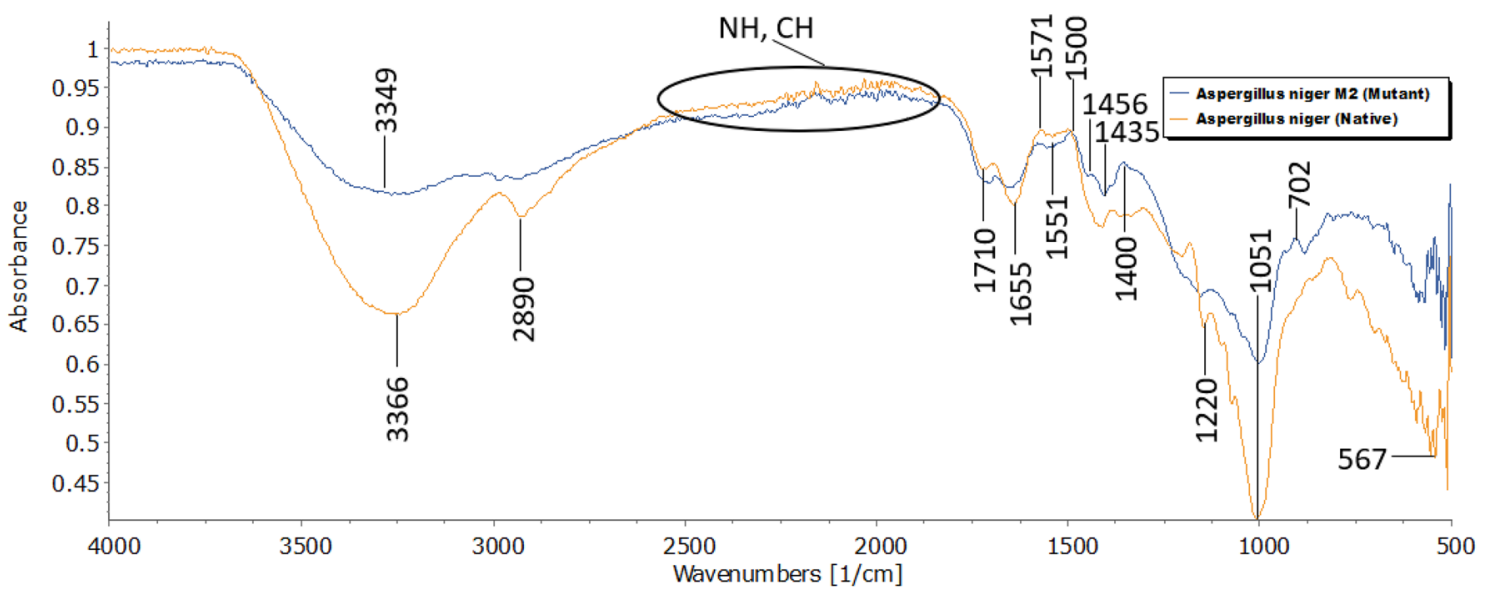

Fig. 3 FT-IR spectra of lyophilized biosurfactant produced by native and mutant strains of $A$. niger 
the response ( $\mathrm{g} / \mathrm{L}$ of biosurfactant yield) was determined. Total biosurfactant yield was in the range of $2.8-5.5 \mathrm{~g} / \mathrm{L}$ depending upon fermentation conditions provided. The lowest yield was obtained at $35^{\circ} \mathrm{C}$ temperature, $5.5 \mathrm{pH}$, $4.5 \mathrm{~g}$ substrate concentration and incubation of $168 \mathrm{~h}$. The maximum biosurfactant yield $(5.5 \mathrm{~g} / \mathrm{L})$ was obtained at $35^{\circ} \mathrm{C}$ temperature, $7 \mathrm{pH}, 5.57 \mathrm{~g}$ substrate concentration and an overall incubation period of $168 \mathrm{~h}$. The model was analyzed using Design-Expert software and the 3D response surface graphs were constructed.

The response surface model significance and fitness were analyzed by the determination of ANOVA variant for quadratic model and each individual factor was tested using F-values and $p$-values. ANOVA for RSM quadratic model for biosurfactant production under optimized conditions has been represented in Table 2. The high model F value (2.743) showed that the model is significant. The lack of fit value was insignificant indicating the model appropriateness. These results showed the quality and the fitness of the RSM and its capability to predict the response within the range of variables used. RSM model suggested the quadratic equation for the total biosurfactant yield which can be expressed as follows: where $\mathrm{X} 1, \mathrm{X} 2, \mathrm{X} 3$ and $\mathrm{X} 4$ are the codded values of the relating factors temperature, $\mathrm{pH}$, incubation time and substrate concentration.

Temperature and $\mathrm{pH}$ are the great influencer of biosurfactant production during fermentation. The optimum production occurs in the specific range where the microorganism is most active. In case of Aspergillus strains, the optimum growth temperature lies between 30 and $40{ }^{\circ} \mathrm{C}$ and a $\mathrm{pH}$ ranging from 6 to 7 . This indicates the high temperature and $\mathrm{pH}$ dependency of biosurfactant production process. In this study, maximum biosurfactant production was obtained at $\mathrm{pH} 7$ and $35^{\circ} \mathrm{C}$ temperature. Figure $4 \mathrm{a}$ presents the effect of temperature and $\mathrm{pH}$ on biosurfactant yield at fixed value of substrate concentration and fermentation time. Since the optimum $\mathrm{pH}$ for Aspergillus strains is $6.5-7$, the production was drastically reduced at end points of $\mathrm{pH}$ variable. Temperature was also the critical parameter that have been controlled in bioprocess. Strain A. niger $\mathrm{M} 2$ showed maximum activity at $30-40{ }^{\circ} \mathrm{C}$ temperature with maximum biosurfactant production at $35^{\circ} \mathrm{C}$ (Fig. 4a).

Incubation time was found to be one of the most influencer of biosurfactant production. Biosurfactant

$$
\begin{aligned}
\text { Biosurfactant yield }(\mathrm{g} / \mathrm{L})= & 2.05+0.0784(\mathrm{X} 1)+0.0166(\mathrm{X} 2)+0.0157(\mathrm{X} 3) \\
& +0.0353(\mathrm{X} 4)+0.0441(\mathrm{X} 1 \times \mathrm{X} 2)+0.0206(\mathrm{X} 1 \times \mathrm{X} 3) \\
& +0.0212(\mathrm{X} 1 \times \mathrm{X} 4)-0.0027(\mathrm{X} 2 \times \mathrm{X} 3)+0.0234(\mathrm{X} 2 \times \mathrm{X} 4) \\
& -0.0134(\mathrm{X} 3 \times \mathrm{X} 4)+0.3274\left(\mathrm{X}^{2}\right)-0.5901\left(\mathrm{X2} 2^{2}\right) \\
& -0.9827\left(\mathrm{X}^{2}\right)+1.09\left(\mathrm{X}^{2}\right)
\end{aligned}
$$

\begin{tabular}{|c|c|c|c|c|c|c|}
\hline Source & Sum of squares & $d f$ & Mean square & F value & $p$ value & \\
\hline Model & 22.15 & 14 & 1.58 & 36.29 & 0.000 & Significant \\
\hline A-temperature & 0.116 & 1 & 0.117 & 2.68 & 0.002 & \\
\hline B-pH & 0.136 & 1 & 0.136 & 3.13 & 0.007 & \\
\hline C-incubation time & 0.434 & 1 & 0.434 & 9.96 & 0.006 & \\
\hline D-substrate concentration & 0.012 & 1 & 0.013 & 0.294 & 0.005 & \\
\hline$A B$ & 1.95 & 1 & 1.95 & 44.63 & $<0.000$ & \\
\hline$A C$ & 0.230 & 1 & 0.231 & 5.29 & 0.036 & \\
\hline$A D$ & 0.024 & 1 & 0.024 & 0.551 & 0.009 & \\
\hline $\mathrm{BC}$ & 0.176 & 1 & 0.176 & 4.05 & 0.002 & \\
\hline $\mathrm{BD}$ & 0.000 & 1 & 0.001 & 0.009 & 0.925 & \\
\hline$C D$ & 0.144 & 1 & 0.144 & 3.31 & 0.088 & \\
\hline$A^{2}$ & 0.176 & 1 & 0.176 & 4.04 & 0.062 & \\
\hline$B^{2}$ & 0.469 & 1 & 0.470 & 10.77 & 0.005 & \\
\hline$C^{2}$ & 0.030 & 1 & 0.031 & 0.702 & 0.415 & \\
\hline$D^{2}$ & 0.073 & 1 & 0.074 & 1.69 & 0.213 & \\
\hline Residual & 0.654 & 15 & 0.044 & & & \\
\hline Lack of fit & 0.588 & 10 & 0.059 & 4.46 & 0.0562 & Not significant \\
\hline Pure error & 0.065 & 5 & 0.014 & & & \\
\hline Cor total & 22.80 & 29 & & & & \\
\hline
\end{tabular}

Table 2 Analysis of variance (ANOVA) for response surface model for the development of biosurfactant by A. niger $\mathrm{M} 2$ 

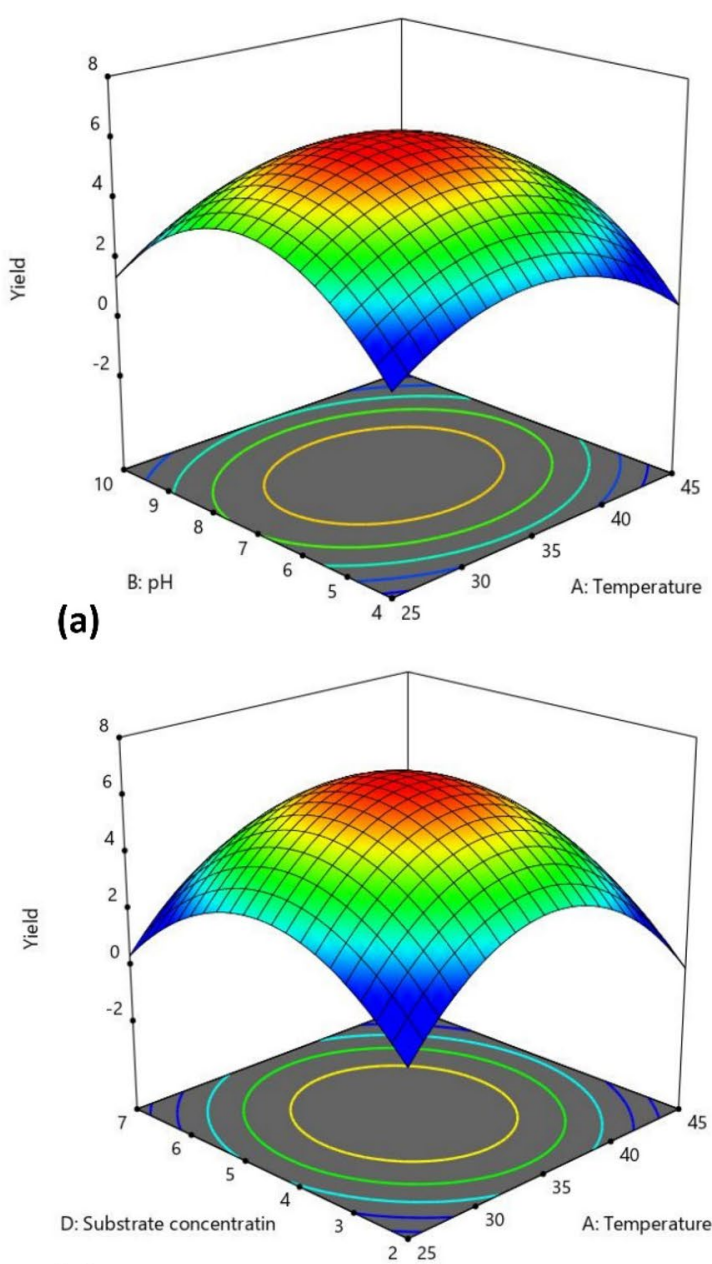

(c)

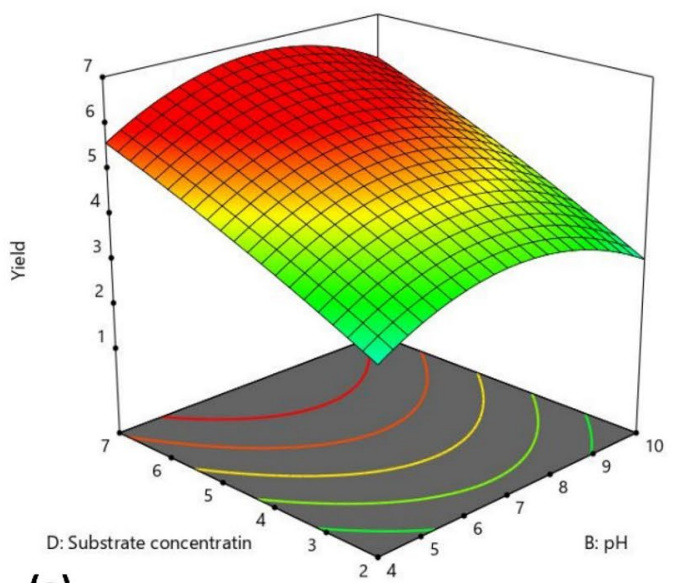

(e)

Fig. 4 Response surface three-dimensional (3D) plots showing interaction between a temperature versus $\mathrm{pH}$ b temperature versus incubation time $\mathbf{c}$ temperature versus substrate concentration

production was maximum after $168 \mathrm{~h}$ of incubation in SSF of banana stalks powder. The production was equally decreased at higher or lower values of incubation time

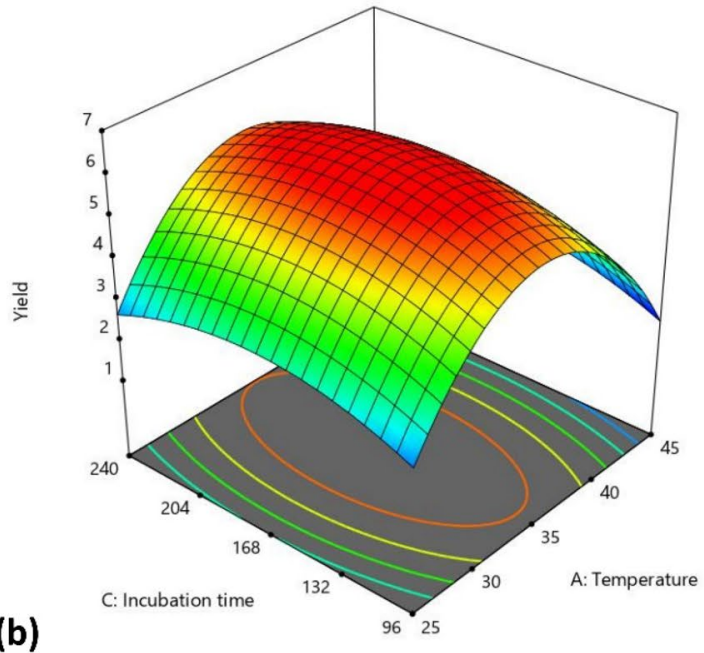

(b)

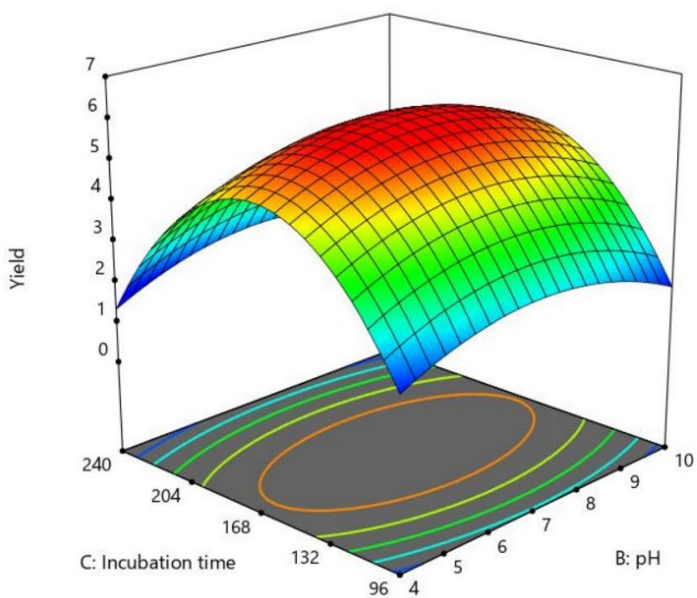

(d)

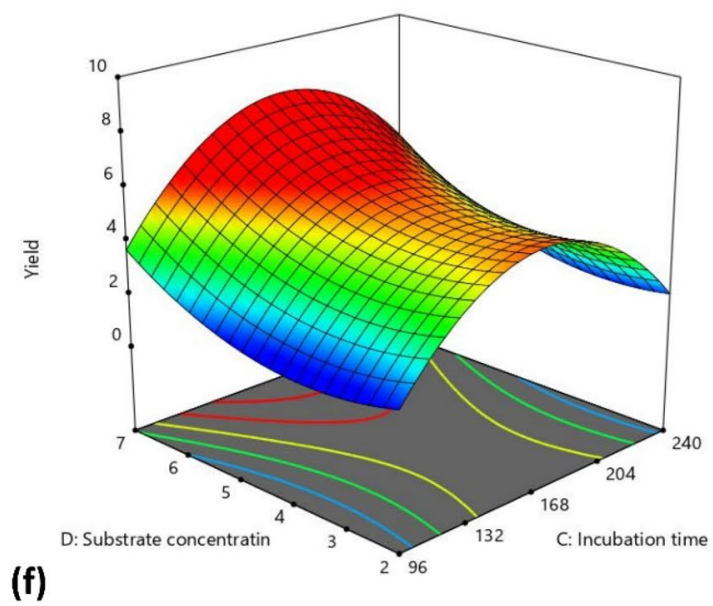

d $\mathrm{pH}$ versus incubation time $\mathbf{e} \mathrm{pH}$ versus substrate concentration $\mathbf{f}$ incubation time versus substrate concentration

than $168 \mathrm{~h}$. Figure $4 \mathrm{~b}$ shows the interaction between temperature and incubation time by keeping other factors constant. Any deviation from $168 \mathrm{~h}$ of incubation leads to 
the decline in biosurfactant production from A. niger M2. The strains showed maximum production after $168 \mathrm{~h}$ in the exponential growth phase of the specie.

The joint effect of temperature and substrate concentration has been represented in Fig. $4 \mathrm{c}$ by keeping $\mathrm{pH}$ and incubation time constant. The biosurfactant yield was maximum at $4-5 \mathrm{~g}$ of substrate and the yield was equally decreased at upper and lower level of factor. The maximum biosurfactant production was achieved at $5.75 \mathrm{~g}$ of substrate concentration where the factor was at +1 level of the design. Figure $4 \mathrm{~d}$ shows the joint effect of $\mathrm{pH}$ and incubation time on biosurfactant production by keeping other factors constant. Maximum biosurfactant production was obtained at $\mathrm{pH} 6$ to 7 and $168 \mathrm{~h}$ of incubation in SSF. The production was equally declined at higher and lower level of these factors, but the $\mathrm{pH}$ was less influencing the production as compared with incubation time.

The effect of $\mathrm{pH}$ versus substrate concentration has been displayed in Fig. 4e by keeping constant values of temperature and incubation time. In the figure, substrate concentration positively influenced the biosurfactant production, means the yield was increased by increase in substrate concentration, whereas, at pH 6 to 7 , yield was optimum which gradually decreased by moving towards extreme points, but the reduction was generally lower. Figure $4 \mathrm{f}$ shows the interaction between incubation period and substrate concentration by keeping temperature and $\mathrm{pH}$ constant. Highest yield was obtained at 6 to $7 \mathrm{~g}$ substrate concentration and incubation period of $168 \mathrm{~h}$.

\section{Discussion}

The production of microbial surfactants has gained high importance from previous decade, especially due to their potential applications in biomedical and industrial biotechnological sectors. Oil displacement, Emulsification activity and emulsification index has been used for the estimation of biosurfactant [32, 38-40]. Therefore, using such strategy, biosurfactant production from $A$. niger was screened after random mutagenesis for the selection of highest biosurfactant producer mutant strain. Furthermore, quantification using dry weight estimation made the selection more convenient. Biosurfactant production from fungal species have extensively been described from Aspergillus spp. [41-44] using various synthetic and biobased substrates, but herein, mutant $A$. niger (M2) produce significantly higher amount of biosurfactant $(3.3 \mathrm{~g} / \mathrm{L}$ ) as compared with previous studies using native $A$. niger strain. The mutant (A. niger M2) exhibited high emulsification index and oil displacement as compared to native strain (Table 1).

\section{SN Applied Sciences}

Despite having several commercially attractive characteristics compared with synthetic surfactants, the production of commercial scale biosurfactants from microbial origin has not been realized because of their high production cost and significantly low yield. There are two basic strategies that are being adopted by the biotechnologists for economical biosurfactant production, which corresponds, the use of low-cost waste materials to reduce the overall substrate cost and the efficient bioprocesses, including optimized fermentation parameters involving multiple physical and nutritional factors [45]. The selection of appropriate substrate is a crucial step in the production of biosurfactant, as the substrate account for overall $10-30 \%$ cost of the experiment $[45,46]$. Therefore, in this context, herein, a cost-effective process was developed for the production of biosurfactant using agro-industrial raw-material (banana stalks powder) with waste-to-value approach. The production of significant amount of biosurfactant using banana stalks waste revealed the compatibility of the medium. Hence, the reported medium composition was selected for the next experiments.

The biosurfactant production during logarithmic growth phase and stationary phase of microorganisms have already been studied from various fungal species e.g., A. ustus [42], A. niger [43, 44], A. flavus [43, 46], A. versicolor [47], and Piper hispidum [48], and various factors influencing the total biosurfactant yield during fermentation have broadly been studied in previous few decades [42, 49-54]. From these, several studies have reported classical methods for optimization purpose by placing one factor as constant and modifying another one. In this research, we have applied a proper tool (RSM) for the optimization of different factors that influence biosurfactant production from A. niger $\mathrm{M} 2$ during fermentation. One of the advantages of this mutant (A. niger M2) is the highest amount of biosurfactant production with maximum emulsification activity, which make it capable for several industrial applications such as microbially enhanced oil recovery $[30,38]$.

After optimization using RSM-CCD, maximum biosurfactant production $(5.5 \mathrm{~g} / \mathrm{L})$ was attained which was 2.5 -folds higher than the biomass obtained from native strain and about 1.7-folds higher than the mutant strain (A. niger M2). These results clearly suggest a significantly higher amount of biosurfactant as compared with previous studies. The central composite design (CCD) during RSM enabled us to investigate different fermentation parameters that support biosurfactant overproduction. A close association was observed between $R^{2}(0.820)$ and predicted $R^{2}(0.794)$, which reflected the compatibility and suitability of methodology to optimize biosurfactant production. The maximum yield was obtained at $35^{\circ} \mathrm{C}$ temperature, $7 \mathrm{pH}, 5.75 \mathrm{~g}$ substrate concentration and $168 \mathrm{~h}$ of overall fermentation period. Any change 
(increase of decrease) in one of these parameters may cause decrease in biosurfactant production. The biosurfactant yield $(5.5 \mathrm{~g} / \mathrm{L})$ from A. niger $\mathrm{M} 2$ is the highest reported yield from Aspergillus species in solid state fermentation.

In addition, the use of banana stalks waste as a substrate in SSF for biosurfactant production by $A$. niger is novel. The production cost would be significantly reduced via experimental design described in this study using optimized fermentation conditions. The insights of fungal surfactants and their significant characteristics have also been studied in this research. The stability of biosurfactant obtained from A. niger M2 over a wide temperature range indicates its activity at extreme environmental conditions, which is an amazing feature for its potential use in biomedical and industrial biotechnological sectors including microbial enhanced oil recovery and bioremediation $[9,12]$. In conclusion, we have successfully improved the biosurfactant production about 1.5-folds after random chemical mutagenesis of $A$. niger using banana stalks powder as low-cost substrate following waste-to-value idea (from 2.3 to $3.3 \mathrm{~g} / \mathrm{L}$ ).

\section{Conclusion}

In this study, biosurfactant production was successfully enhanced about 1.5-folds after EtBr mutagenesis of $A$. niger using agro-industrial waste (banana stalks powder) as low-cost substrate. Optimization of fermentation parameters was performed using statistical approach (RSM-CCD) to maximize the yield. After optimization, maximum biosurfactant yield $(5.5 \mathrm{~g} / \mathrm{L}$ ) was attained, which was significantly higher from both native as well as mutant strains (before optimization) i.e., 2.5-folds and 1.7-folds respectively. In conclusion, the biosurfactants produced from $A$. niger were a kind of surface-active substances, having potential applications in biomedical and industrial biotechnological sectors including enhanced oil recovery and bioremediation. To the best of our knowledge, this the first study reporting mutagenesis of $A$. niger for improved biosurfactant production and process optimization using cost-effective agro-industrial waste as substrate.

Acknowledgements This study was supported by Higher Education Commission (HEC), Islamabad, Pakistan under grant number NRPU 6417. The analytical facilities provided by Department of Biochemistry and Punjab Bioenergy Institute (PBI), University of Agriculture, Faisalabad, Pakistan are thankfully acknowledged.

\section{Compliance with ethical standards}

Conflict of interest The authors declared that they have no conflict of interest.

\section{References}

1. Mukherjee S, Das P, Sen R (2006) Towards commercial production of microbial surfactants. Trends Biotechnol 24:509-515. https://doi.org/10.1016/j.tibtech.2006.09.005

2. Van Hamme JD, Singh A, Ward OP (2006) Physiological aspects: part 1 in a series of papers devoted to surfactants in microbiology and biotechnology. Biotechnol Adv 24:604-620. https://doi. org/10.1016/j.biotechadv.2006.08.001

3. Mulligan CN (2009) Recent advances in the environmental applications of biosurfactants. Curr Opin Colloid Interface Sci 14:372-378. https://doi.org/10.1016/j.cocis.2009.06.005

4. Banat IM, Rengathavasi T (2018) Microbial biosurfactants and their environmental and industrial applications. CRC Press. ISSN: 9781315271767. https://doi.org/10.3390/app8091555

5. Janek T, Czyznikowska Z, Lukaszewicz M, Gałęzowska J (2019) The effect of Pseudomonas fluorescens biosurfactant pseudofactin II on the conformational changes of bovine serum albumin: pharmaceutical and biomedical applications. J Mol Liq 288:111001. https://doi.org/10.1016/j.molliq.2019.111001

6. Satpute SK, Mone NS, Das P, Banat IM (2019) Inhibition of pathogenic bacterial biofilms on PDMS based implants by L. acidophilus derived biosurfactant. BMC Microbiol. 19:39. https://doi. org/10.1186/s12866-019-1412-Z

7. Satpute S, Mone N, Das P, Banpurkar A (2018) Lactobacillus acidophilus derived biosurfactant as a biofilm inhibitor: a promising investigation using microfluidic approach. Appl Sci 8:1555. https://doi.org/10.3390/app8091555

8. Mnif I, Ghribi D (2015) Review lipopeptides biosurfactants: mean classes and new insights for industrial, biomedical, and environmental applications. J Pept Sci 104:129-147. https://doi. org/10.1002/bip.22630

9. Silva EJ, Correa PF, Almeida DG, Luna JM (2018) Recovery of contaminated marine environments by biosurfactant-enhanced bioremediation. Colloids Surf B 172:127-135. https://doi. org/10.1016/j.colsurfb.2018.08.034

10. Reis RS, Pacheco GJ, Pereira AG, Freire DM (2013) Biosurfactants: production and applications, biodegradation-life of science, Dr. Rolando Chamy. InTech, London. https://doi.org/10.5772/56144

11. Law SQ, Mettu S, Ashokkumar M, Scales PJ (2018) Emulsifying properties of ruptured microalgae cells: barriers to lipid extraction or promising biosurfactants? Colloids Surf B 170:438-446. https://doi.org/10.1016/j.colsurfb.2018.06.047

12. Bouassida M, Fourati N, Ghazala I, Ellouze-Chaabouni S (2018) Potential application of Bacillus subtilis SPB1 biosurfactants in laundry detergent formulations: compatibility study with detergent ingredients and washing performance. Eng Life Sci 18:70-77. https://doi.org/10.1002/elsc.201700152

13. Santos DK, Resende AH, de Almeida DG, Soares da Silva RD (2017) Candida lipolytica UCP0988 biosurfactant: potential as a bioremediation agent and in formulating a commercial related product. Front Microbiol. 8:767. https://doi.org/10.3389/fmicb .2017 .00767

14. Peele KA, Ch VR, Kodali VP (2016) Emulsifying activity of a biosurfactant produced by a marine bacterium. 3 Biotech 6:177. https://doi.org/10.1007/s13205-016-0494-7

15. Gaur VK, Regar RK, Dhiman N, Gautam K (2019) Biosynthesis and characterization of sophorolipid biosurfactant by Candida 
spp.: application as food emulsifier and antibacterial agent. Bioresour Technol 285:121314. https://doi.org/10.1016/j.biort ech.2019.121314

16. Mohammed IU, Deeni Y, Hapca SM, McLaughlin K (2015) Predicting the minimum liquid surface tension activity of pseudomonads expressing biosurfactants. Lett Appl Microbiol 60:37-43. https://doi.org/10.1111/lam.12331

17. Nitschke M, Pastore GM (2016) Production and properties of a surfactant obtained from Bacillus subtilis grown on cassava wastewater. Bioresour Technol 97(2):336-341. https://doi. org/10.1016/j.biortech.2005.02.044

18. Lang S, Wagner F (2017) Structure and properties of biosurfactants. Biosurfactants Biotechnol 2017:21-45. https://doi. org/10.1201/9781315138428

19. Banat IM, Franzetti A, Gandolfi I, Bestetti G (2010) Microbial biosurfactants production, applications and future potential. Appl Microbiol Biotechnol 87:427-444. https://doi.org/10.1007/s0025 3-010-2589-0

20. Abouseoud M, Maachi R, Amrane A, Boudergua S (2008) Evaluation of different carbon and nitrogen sources in production of biosurfactant by Pseudomonas fluorescens. Desalination 223:143-151. https://doi.org/10.1016/j.desal.2007.01.198

21. Kumar AP, Janardhan A, Radha S, Viswanath B (2015) Statistical approach to optimize production of biosurfactant by Pseudomonas aeruginosa 2297. 3 Biotech 5:71-79. https://doi. org/10.1007/s13205-014-0203-3

22. Oluwaseun AC, Kola OJ, Mishra P, Singh JR (2017) Characterization and optimization of a rhamnolipid from Pseudomonas aeruginosa $\mathrm{C} 1501$ with novel biosurfactant activities. Sustain Chem Pharm 6:26-36. https://doi.org/10.1016/j.scp.2017.07.001

23. Brasileiro PP, de Almeidab DG, de Lunaa JM, Rufinoa RD (2015) Optimization of biosurfactant production from Candida guiliermondii using a rotate central composed design. Chem Eng. https://doi.org/10.3303/CET1543236

24. Luna JM, Santos Filho A, Rufino RD, Sarubbo L (2016) Production of biosurfactant from Candida bombicola URM 3718 for environmental applications. Chem Eng Trans 49:583-588. https://doi. org/10.3303/CET1649098

25. Almeida DG, Soares da Silva RD, Luna JM, Rufino RD (2017) Response surface methodology for optimizing the production of biosurfactant by Candida tropicalis on industrial waste substrates. Front Microbiol 8:157. https://doi.org/10.3389/fmicb 2017.00157

26. Suryanti V, Hastuti S, Andriani D (2016) Optimization of biosurfactant production in soybean oil by Rhodococcus rhodochrous and its utilization in remediation of cadmium-contaminated solution. IOP Conf Ser Mater Sci Eng 107:012018. https://doi. org/10.1088/1757-899X/107/1/012018

27. Kim CH, Lee DW, Heo YM, Lee H (2019) Desorption and solubilization of anthracene by a rhamnolipid biosurfactant from Rhodococcus fascians. Water Environ Res. https://doi.org/10.1002/ wer.1103

28. Fooladi T, Moazami N, Abdeshahian P, Kadier A (2016) Characterization, production and optimization of lipopeptide biosurfactant by new strain Bacillus pumilus 2IR isolated from an Iranian oil field. J Petrol Sci Eng 145:510-519. https://doi. org/10.1016/j.petrol.2016.06.015

29. Moshtagh B, Hawboldt K, Zhang B (2018) Optimization of biosurfactant production by Bacillus Subtilis N3-1P using the brewery waste as the carbon source. Environ Technol 2018:1. https:// doi.org/10.1080/09593330.2018.1473502

30. Ghazala I, Bouallegue A, Haddar A, Ellouz-Chaabouni S (2018) Characterization and production optimization of biosurfactants by Bacillus mojavensis 14 with biotechnological potential for microbial enhanced oil recovery. Biodegradation 2018:1. https ://doi.org/10.1007/s10532-018-9844-y
31. Deepika KV, Kalam S, Sridhar PR, Podile AR (2016) Optimization of rhamnolipid biosurfactant production by mangrove sediment bacterium Pseudomonas aeruginosa KVD-HR42 using response surface methodology. Biocatal Agric Biotechnol 5:3847. https://doi.org/10.1016/j.bcab.2015.11.006

32. Mouafi FE, Elsoud MM, Moharam ME (2016) Optimization of biosurfactant production by Bacillus brevis using response surface methodology. Biotechnol Rep 9:31-37. https://doi. org/10.1016/j.btre.2015.12.003

33. Maheshwari N, Kumar M, Thakur IS, Srivastava S (2017) Recycling of carbon dioxide by free air $\mathrm{CO}_{2}$ enriched (FACE) Bacillus sp. SS105 for enhanced production and optimization of biosurfactant. Bioresour Technol 242:2-6. https://doi. org/10.1016/j.biortech.2017.03.124

34. Vogel HJ (1964) Distribution of lysine pathways among fungi: evolutionary implications. Am Nat 98:435-446

35. Lee CA, Jones BD, Falkow S (1992) Identification of a Salmonella typhimurium invasion locus by selection for hyperinvasive mutants. Proc Natl Acad Sci 89:1847-1851. https://doi. org/10.1073/pnas.89.5.1847

36. Fiedurek J, Paszczynski A, Ginalska G, Ilczuk Z (1987) Selection of amylolytically active Aspergillus niger mutants to 2-deoxyD-glucose. Zentralblatt für Mikrobiologie. 142:407-412. https ://doi.org/10.1016/S0232-4393(87)80089-6

37. Morikawa M, Hirata Y, Imanaka TA (2000) A study on the structure-function relationship of lipopeptide biosurfactants. BBAMol Cell Biol Lipid 1488:211-218. https://doi.org/10.1016/ S1388-1981(00)00124-4

38. Alvarez VM, Jurelevicius D, Marques JM, de Souza PM (2015) Bacillus amyloliquefaciens TSBSO 3.8, a biosurfactant-producing strain with biotechnological potential for microbial enhanced oil recovery. Colloids Surf B 136:14-21. https://doi. org/10.1016/j.colsurfb.2015.08.046

39. Patel RM, Desai AJ (1997) Surface-active properties of rhamnolipids from Pseudomonas aeruginosa GS3. J Basic Microbiol 37:281-286. https://doi.org/10.1002/jobm.3620370407

40. Ghribi D, Abdelkefi-Mesrati L, Mnif I, Kammoun R (2012) Investigation of antimicrobial activity and statistical optimization of Bacillus subtilis SPB1 biosurfactant production in solid-state fermentation. J Biomed Biotechnol. https://doi. org/10.1155/2012/373682

41. Bezerra KG, Rufino RD, Luna JM, Sarubbo LA (2018) Saponins and microbial biosurfactants: potential raw materials for the formulation of cosmetics. Biotechnol Prog 34:1482-1493. https://doi.org/10.1002/btpr.2682

42. Kiran GS, Hema TA, Gandhimathi R, Selvin J (2009) Optimization and production of a biosurfactant from the spongeassociated marine fungus Aspergillus ustus MSF3. Colloids Surf B 73:250-256. https://doi.org/10.1016/j.colsurfb.2009.05.025

43. Adekunle AT, Ester BB, Olabisi A, Peter OS (2015) Characterization of new glycosophorolipid-surfactant produced by Aspergillus niger and Aspergillus flavus. Eur J Biotechnol Biosci 3:34-39

44. Superb JG, Costa TM, Bertoli SL, Tavares LB (2018) Simultaneous production of biosurfactants and lipases from Aspergillus niger and optimization by response surface methodology and desirability functions. Braz J Chem Eng 35:857-868. https://doi. org/10.1590/0104-6632.20180353s20160400

45. Asgher M, Urooj Y, Qamar SA, Khalid N (2020) Improved exopolysaccharide production from Bacillus licheniformis MS3: optimization and structural/functional characterization. Int J Biol Macromol. https://doi.org/10.1016/j.ijbiomac.2019.11.094

46. Ishaq U, Akram MS, Iqbal Z, Rafiq M (2015) Production and characterization of novel self-assembling biosurfactants from Aspergillus flavus. J Appl Microbiol 119:1035-1045. https://doi. org/10.1111/jam.12929 
47. Gul UD, Donmez G (2012) Effects of dodecyl trimethyl ammonium bromide surfactant on decolorization of Remazol Blue by a living Aspergillus versicolor strain. J Surfactants Deterg 15:797803. https://doi.org/10.1007/s11743-012-1377-5

48. da Silva ME, Duvoisin S Jr, Oliveira RL, dos Banhos EF (2019) Biosurfactant production of Piper hispidum endophytic fungi. J Appl Microbiol. https://doi.org/10.1111/jam.14398

49. Seghal Kiran G, Thajuddin N, Hema TA, Idhayadhulla A (2010) Optimization and characterization of rhamnolipid biosurfactant from sponge associated marine fungi Aspergillus sp. MSF1. Desalin Water Treat 24:257-265. https://doi.org/10.5004/ dwt.2010.1569

50. Velioglu Z, Urek RO (2015) Optimization of cultural conditions for biosurfactant production by Pleurotus djamor in solid state fermentation. J Biosci Bioeng 120:526-531. https://doi. org/10.1016/j.jbiosc.2015.03.007

51. Meneses DP, Gudina EJ, Fernandes F, Goncalves LR (2017) The yeast-like fungus Aureobasidium thailandense LB01 produces a new biosurfactant using olive oil mill wastewater as an inducer. Microbiol Res 204:40-47. https://doi.org/10.1016/j.micre s.2017.07.004
52. Reis CB, Morandini LM, Bevilacqua CB, Bublitz F (2018) First report of the production of a potent biosurfactant with $a$ $\beta$-trehalose by Fusarium fujikuroi under optimized conditions of submerged fermentation. Braz J Microbiol 49:185-192. https ://doi.org/10.1016/j.bjm.2018.04.004

53. Nalini S, Parthasarathi R (2018) Optimization of rhamnolipid biosurfactant production from Serratia rubidaea SNAU02 under solid-state fermentation and its biocontrol efficacy against Fusarium wilt of eggplant. Ann Agrar Sci 16:108-115. https:// doi.org/10.1016/j.aasci.2017.11.002

54. Hema T, Kiran GS, Sajayyan A, Ravendran A (2019) Response surface optimization of a glycolipid biosurfactant produced by a sponge associated marine bacterium Planococcus sp. MMD26. Biocatal Agric Biotechnol 18:101071. https://doi.org/10.1016/j. bcab.2019.101071

Publisher's Note Springer Nature remains neutral with regard to jurisdictional claims in published maps and institutional affiliations. 